\title{
Medico-ecological aspects of hydrochemistry of Uzbekistan
}

\author{
E. Kamilova \& G. Rakhmatkariev ${ }^{1}$ \\ ${ }^{I}$ Institute of General and Inorganic Chemistry, \\ Academy of Sciences of Uzbekistan, Tashkent, Uzbekistan.
}

\section{Abstract}

Investigation of the relationship between environmental changes and population health constitutes one of the most important parts of human ecology. An integrated study of the ecological and sanitary status of water resources in Uzbekistan, and a description interrelations between rate of their contamination and population health status are presented in this paper. Concentration of manganese, iron, cobalt, zinc, cadmium, chromium, rubidium, selenium, scandium antimony, strontium, lithium, lead, mercury, silver, aluminum, beryllium, molybdenum, nickel, tin and copper were detected by method of Atomic Absorption Spectrophotometry. It was revealed that strontium and lithium contents exceed the maximum permissible concentration (MPC) in water sources of Bukhara Region. In the surface water near Akhangaran, Chirchik and Almalyk the content of cadmium, lead and mercury exceed MPC. High content of cadmium and mercury were detected revealed in the samples of drinking water of Tashkent City and Tashkent Region.

A lack of drinking water, and general poor water quality are typical in the Aral Region define to Uzbekistan. Water deficit is caused by excessive water withdrawal for irrigation and drainage of agricultural fields. Livestock wastes, agriculture chemicals, urban and industrial wastes, all pollute water sources in this region. A high level of intestinal and gastro-intestinal diseases, as well as hepatitis morbidity was observed in the Aral Sea area. The number of people suffering from pathology of alimentary canal, liver and kidney, cardiovascular diseases is increasing. Esophagus cancer morbidity is the highest detected in the Republic. However, heavy metals with concentration exceeding the MPC were not found in water sources drinking water. The main reasons proposed for high morbidity rate in Aral Region are following:

1)Low-quality of drinking water (Syrdarya and Amydarya Rivers, water from irrigation canals, brackish and desalinized groundwater);2)Increasing water mineralization, especially in the lower reaches of the rivers; 3)Bacterial contamination (E-coli and pathogenic microorganisms), pollution by pesticides and herbicides, defoliants. 


\section{Introduction}

Investigation of relations between environmental changes and the status of the population health constitutes one of the most important parts of human ecology.

Lack of good-quality drinking water is characteristic of arid regions.

According to our data, current water deficit conditions, in Uzbekistan aggravated further. Current consumption patterns pose the danger of a qualitative and quantitative exhaustion of water resources, amplified in present conditions of constant growth of requirements it in our Republic.

The contamination of surface water is wide spread and to extends to underground waters in areas of use. For last 15-20 years in Bukhara, Karakul and Karmaninsky oases underground water usable for drinking purposes have completely disappeared. The catastrophic deterioration of underground water quality of Khoresm, Turtkul, Khodjailinsky and Nukus-Chimbaisky oases, in the lower course of Chirchik, Syrkhandaria, Seravshan rivers, Sanzar and Dalverzin regions, Fergana valley etc. (Mirzaev, [1]) began at this time.

The large chemical enterprises present in territory of Uzbekistan, especially in Chirchik, Almalyk etc., create conditions for emission of heavy metals initially into the environment, make its way into the water.

For example, the Almalyk Mining Industry Integrated Plant (AM IP) is one of the largest plants of Uzbekistan, including a number of large industrial projects such as mines and factories. Despite of the use in AM IP of turnaround systems of water supply, it is important to note that the structure of waste pollutants here include more than 20 components: petroleum, phenols, kantogenats, reagents used for flotation, rhodanides, cyanides, ammonia, nitrates, paraffin, petroleum and ions of heavy metals.

The wide range of these chemicals are not biologically degradable, and then they do break down, they poison numerous kinds of living organisms. The structure of residuals include large amounts of zinc, lead, mercury, fluorine, which by various ways will penetrate into water reservoirs and finally, together with food will get into the human organism. All these pollutants are highly dangerous to human health (Namazov, [2]).

The negative effect of high content of heavy metals on population health is well-known. For example, cadmium causes to kidney troubles, cancer of prostate, "itay-itay" disease (symptoms of this disease include skeletal softening because loss of calcium).

Manganese causes to Parkinson's disease, defeat of the central nervous system;

copper - anemia, disturbances of the central nervous system, exhaustion, decrease of plasticity of vascular blood system (in case of insufficiency), hepatitis, schizophrenia, development of tumors (in high concentrations);

lead -central nervous system problems, defeat of liver, kidneys, brain, sexual organs, it's influence is cancerogenic and mutagenic (in excess concentrations); 
selenium -intestinal infringement, dermatitis, arthritis, hair loss, weakness, collapse (in excess concentrations);

zinc -anemia, promotes division of cancer cells (in excess concentrations), diabetes, delay of growth and on-set of puberty;

iron - liver cirrhosis, infringement of blood circulation system.

In recently years, the Government of Uzbekistan has made efforts to improve this situation, and has had some success. Institute of General and Inorganic Chemistry of the Academy of Sciences of Uzbekistan is promoting investigation of new technologies of filters for cleaning drinking water (reverse osmosis membrane) .

In order develop concrete measures of improvement of ecological conditions in Uzbekistan it is necessary to carry out complete monitoring of the water supply particularly toxic metal levels. The present investigation is an attempt to determining the relationship between environmental changes and population health in Uzbekistan.

\section{Materials and methods}

The investigation was conducted over the last 3 years together with Institute of Hydrogeology, the employees of the Laboratory of Elemental Analysis of Institute of General and Inorganic Chemistry of Academy of Sciences of Uzbekistan using Atomic Absorption Spectrophotometry (with the Perkin-Elmer 3030B Atomic Absorption Spectrophotometer ). Part of the analyses was carried out on updating of the device Perkin-Elmer Z3030, that has allowed to determine the contents of beryllium, gold, silver etc.

" Environmental compliance Standard PCS-1 (Pollution Control Standard \#1), and Standards of the Central laboratory of ecological, hydrochemical and engineering -geological researches of the Ministries of geology of Kazakhstan were used as standards for assessment of water quality.

\subsection{Heavy metals extraction.}

Heavy metals were extracted from water samples by using two methods:

1. Evaporation with addition of $\mathrm{HNO}_{3}$ acid [3, 4];

2. Extraction in organic phase (butylacetate or ethylacetate) [Kariakin, 5, 6].

In both methods water samples $(100 \mathrm{ml})$ were treated with $\mathrm{HNO}_{3}$ for adjusting $\mathrm{pH}=3$.

In the first method sample was evaporated to minimize volume to $100 \mathrm{ml}$, and used for detection of metals by spread into flame.

In the second method heavy metals were transferred into $10 \mathrm{ml}$ organic phase, by stirring of mixture, and after upholding, organic extract was separated and use for detection of heavy metals. The extract with heavy metals was directly spread in a flame. The standards were transferred into the organic phase.

The data on maximum permissible concentration (MPC) of toxic metals in water were taken from the reference books 7 and 8.( Methodical instructions on definition of damage from pollution and deterioration of soils in republic of 
Uzbekistan, Sanitary rules and norms of protection of surface waters from pollution).

Concentrations of manganese, iron, cobalt, zinc, cadmium, chromium, rubidium, selenium, scandium antimony, strontium, lithium, lead, mercury, silver, aluminum, beryllium, molybdenum, nickel, tin and copper were detected by method of Atomic Absorption Spectrophotometry. The method of Atomic Absorption Spectrophotometry combines high sensitivity with the large productivity. That has allowed possibility to inspect heavy metals content in drinking, underground, waste and surface water practically of all regions of Uzbekistan during 5 years.

\section{Results}

The research detected that strontium (up to $12 \mathrm{mg} / 1$, at (MPC) $7,0 \mathrm{mg} / \mathrm{l}$ ) and lithium contents exceed the MPC in water sourses, including drinking, in Bukhara Region. Genesis of water-bearing horizons cause to this phenomena (Table 1).

Investigation of pollution rate and distribution of industrial emissions of Almalyk Mining Industry Integrated Plant has been established, that the air contains sulfurous anhydride, pairs of sulfuric acid, hydrogen sulfide, oxides of nitrogen, ammonia, fluorine, arsenic, copper, zinc, lead etc. These pollutants are distributed to significant distances (Kamiljanov, [9]).

Nuclear-activate and X-ray-fluorescence methods of analysis of the selected samples of air and atmospheric precipitation, which has been carried out in the Institute of Nuclear Physics of Academy of Sciences of the Republic of Uzbekistan has shown that emissions of this plant contain also mercury, chromium, selenium, wolfram, scandium, iron, cobalt, antimony and others littleknown chemicals, such rubidium, lanthanum, gafnium, samarium, europium and itterbium (Kamiljanov, [9]).

Uzbek plant of refractory and heat resisting metals (UzPRHRM) located on Chirchik was also the object of investigation. UzPRHRM represents the large industrial enterprise of non-ferrous metallurgy delivering production to many branches of the national economy. From the references it is known, that by manufacture of refractory and heat resisting metals most frequently meeting receipts in atmospheric air are oxides of nitrogen, ammonia, dust of molybdenum and wolfram. According to our data, in waste water of UzPRHRM, as well as in drinking water of the area, the contents of molybdenum and wolfram do not exceed MPC. We explain this phenomenon by low ability of the given chemical elements to be dissolved in water.

In surface and drinking water of Akhangaran and Chirchik areas lead, cadmium and mercury exceed Maximum Permissible concentration (Table 2). Lead content here achieves $0.035 \mathrm{mg} / \mathrm{l}$ (MPC for lead is $0.03 \mathrm{mg} / \mathrm{l}$ ). Generally, water contains from 0.020 up to $0,027 \mathrm{mg} / \mathrm{l}$ lead. The received data detect the pollution of the given zone by cadmium, since content of this heavy metal is close to Maximum Permissible concentration in a plenty of the surveyed water 
Table 1. The contents of heavy metals in water of Bukhara region of Uzbekistan (average data for 3 years).

\begin{tabular}{|l|l|l|l|l|l|l|l|}
\hline $\begin{array}{l}\text { Place } \\
\text { of } \\
\text { taken } \\
\text { sample }\end{array}$ & $\begin{array}{l}\mathrm{Cu}, \\
\mathrm{mg} / \mathrm{l}\end{array}$ & $\begin{array}{l}\mathrm{Zn}, \\
\mathrm{mg} / \mathrm{l}\end{array}$ & $\begin{array}{l}\mathrm{Mn}, \\
\mathrm{mg} / \mathrm{l}\end{array}$ & $\begin{array}{l}\mathrm{Pb}, \\
\mathrm{mg} / \mathrm{l}\end{array}$ & $\begin{array}{l}\mathrm{Sr}, \\
\mathrm{mg} / \mathrm{l}\end{array}$ & $\begin{array}{l}\mathrm{Cd}, \\
\mathrm{mg} / 1\end{array}$ & $\begin{array}{l}\mathrm{Li}, \\
\mathrm{mg} / 1\end{array}$ \\
\hline $\begin{array}{l}\text { Imigati- } \\
\text { on } \\
\text { canal, } \\
\text { collect } \\
\text { or\#1 }\end{array}$ & 0.014 & 0.027 & 0.095 & 0.029 & 6.9 & absent & 0.071 \\
\hline $\begin{array}{l}\text { Collec- } \\
\text { tor\#2 }\end{array}$ & 0.021 & 0.027 & 0.080 & 0.027 & 10.5 & absent & 0.083 \\
\hline $\begin{array}{l}\text { Bore } \\
\text { hole } \\
\text { 5M }\end{array}$ & 0.036 & 0.005 & 0.095 & 0.026 & 12.3 & 0.0006 & 0.101 \\
\hline $\begin{array}{l}\text { Well } \\
\text { Shar- } \\
\text { akty }\end{array}$ & 0.001 & 0.018 & 0.09 & 0.027 & 13.9 & $\mathrm{absent}$ & 0.093 \\
\hline $\begin{array}{l}\text { Reser- } \\
\text { voir } \\
\text { Chin- } \\
\text { geldy }\end{array}$ & 0.002 & 0.015 & 0.025 & 0.003 & 12.9 & 0.0006 & 0.070 \\
\hline $\begin{array}{l}\text { Water- } \\
\text { works } \\
\text { Artezi- } \\
\text { Ansky }\end{array}$ & 0.001 & 0.010 & 0.012 & 0.002 & 11.0 & 0.002 & 0.080 \\
\hline MPC & 1.0 & 1.0 & 0.1 & 0.03 & 7.0 & 0.001 & 0.03 \\
\hline
\end{tabular}

(MPC for cadmium is $0.001 \mathrm{mg} / \mathrm{l}$ ). Also was discovered exceeding of Maximum Permissible concentration of nickel and cobalt content (concentration this heavy metals here is from 0,012 up to $0,016 \mathrm{mg} / \mathrm{l}$ ). Chromium, copper, zinc, manganese, beryllium, strontium found here were within the limits of the norm.

In samples of water of various areas of Tashkent-city (capital of Uzbekistan) high concentrations of lead and strontium were not observed. According to our data conditions here have developed safe enough if to compare to another regions of Uzbekistan. However, the excess of Maximum Permissible Concentration of mercury and cadmium was discovered in a number of cases (Table 3). As it is known from the references (Perevozchikov, [10]), this phenomenon is connected with existing geological (melalgenetical) natural factors of receipt of toxic elements in soil. So, on explosive infringements existing on the ground, revealed by results of water-gelio surveying of this place, the migration to the soil surface 
Table 2. The contents of heavy metals in water of an industrial zone near Akhangaran, Chirchik and Almalyk of Uzbekistan (average data for 3 years).

\begin{tabular}{|l|l|l|l|l|l|l|l|}
\hline Place sample taken & $\begin{array}{l}\mathrm{Cu}, \\
\mathrm{mg} / 1\end{array}$ & $\begin{array}{l}\mathrm{Zn}, \\
\mathrm{mg} / \mathrm{l}\end{array}$ & $\begin{array}{l}\mathrm{Mn}, \\
\mathrm{mg} / \mathrm{l}\end{array}$ & $\begin{array}{l}\mathrm{Pb}, \\
\mathrm{mg} / \mathrm{l}\end{array}$ & $\begin{array}{l}\mathrm{Sr}, \\
\mathrm{mg} / \mathrm{l}\end{array}$ & $\begin{array}{l}\mathrm{Cd}, \\
\mathrm{mg} / \mathrm{l}\end{array}$ & $\begin{array}{l}\mathrm{Hg}, \\
\mathrm{mg} / \mathrm{l}\end{array}$ \\
\hline Akhangaran river & absent & absent & 0.055 & 0.010 & 0.75 & $\mathrm{absent}$ & $\mathrm{absent}$ \\
\hline $\begin{array}{l}\text { Almalyk zone, bore } \\
\text { hole \#1 (Aiva-lek) }\end{array}$ & absent & absent & 0.051 & 0.038 & 1.00 & absent & absent \\
\hline Saiga-nak reservoir & absent & absent & 0.089 & 0.043 & 1.25 & absent & $\mathrm{Absent}$ \\
\hline Gazalkent reservoir & 0.005 & 0.021 & 0.071 & 0.029 & 1.00 & 0.001 & 0.0018 \\
\hline Chirchik river & 0.005 & 0.041 & 0.078 & 0.033 & 2.00 & 0.001 & 0.0089 \\
\hline Kibray reservoir & 0.007 & 0.024 & 0.098 & 0.009 & 1.00 & 0.009 & 0.0015 \\
\hline $\begin{array}{l}\text { Purifying tanks, } \\
\text { Gazal-kent-city }\end{array}$ & 0.005 & 0.034 & 0.058 & 0.029 & 1.00 & 0.0012 & 0.0006 \\
\hline MPC & 1.0 & 1.0 & 0.1 & 0.03 & 7.0 & 0.001 & 0.0005 \\
\hline
\end{tabular}

of such toxic element, as mercury (up to $0.05-0.1 \mathrm{mg} / \mathrm{m}^{3}$ of soil air) is established. The spray of such fluids in inhabited buildings structures can represent serious health hazard (Perevozchikov,[10]). According to data, completely meets to our requirements the mineral water "Tashkent", from a source in territory of medical establishment bear the name of Semashko (Table 3 ), in some other mineral waters content of cadmium exceed Maximum Permissible Concentration are overestimated.

Table 3. The contents of heavy metals in water of different regions of Tashkent-city, capital of Uzbekistan (average data for 3 years).

\begin{tabular}{|l|l|l|l|l|l|l|}
\hline Place sample taken & $\mathrm{Cu}, \mathrm{mg} / \mathrm{ln}, \mathrm{mg} /$ & $\mathrm{Mn}, \mathrm{mg} /$ & $\mathrm{Cd}, \mathrm{mg} /$ & $\mathrm{Pb}, \mathrm{mg} / \mathrm{l}$ & $\mathrm{Hg}, \mathrm{mg} / \mathrm{l}$ \\
\hline $\begin{array}{l}\text { Unus-Abad district } \\
\text { of Tashkent, Kora- } \\
\text { Kamush river }\end{array}$ & 0.014 & 0.139 & 0.050 & 0.00095 & 0.013 & $\mathrm{absent}$ \\
\hline $\begin{array}{l}\text { Unus-Abad district } \\
\text { of Tashkent, TV } \\
\text { tower }\end{array}$ & 0.012 & 0.175 & 0.070 & 0.0013 & 0.015 & absent \\
\hline $\begin{array}{l}\text { Bore hole, subway } \\
\text { station Aqwa-park }\end{array}$ & 0.004 & 0.028 & 0.082 & 0.001 & 0.009 & 0.0005 \\
\hline $\begin{array}{l}\text { Bore hole, Subway } \\
\text { station bearing the } \\
\text { name of Kirov }\end{array}$ & 0.004 & 0.034 & 0.065 & 0.0009 & 0.008 & 0.0004 \\
\hline $\begin{array}{l}\text { Mineral water } \\
\text { "Tash-kent" }\end{array}$ & 0.005 & 0.015 & 0.024 & 0.0007 & 0.006 & 0.0003 \\
\hline MPC & 1.0 & 1.0 & 0.1 & 0.0001 & 0.03 & 0.0005 \\
\hline
\end{tabular}

The sanitary conditions of water supply of the population of the Aral Sea Region are characterized by deficit of drinking water and its poor quality. The exhaustion of water resources is caused by excessive water withdrawal of water 
for irrigation and drainage of the agricultural fields. All regional rivers are exposed to intensive pollution by livestock wastes, agriculture chemicals, urban and industrial wastes. In the Karakalpak region, high levels of gastro-intestinal diseases and separate outbreaks of different intensity are registered, (especially hepatitis). The sick rate of non-infectious diseases also grew. Thus, in the KzylOrda Region the amount of people suffering of pathology of alimentary canal, liver and kidneys grew two times, cardio-vascular diseases, two times. Esophagus cancer morbidity here is the highest in the Republic.

However, the results of inspection of surface and drinking water of the Aral Sea Basin Region have not shown pollution of heavy metals which content corresponds to norm (results of investigation of Karabailinsky reservoir ). What is the reason of growth of diseases? The deficit of water brings about the necessity in using low-quality water for drinking (the Syrdaria and Amudaria Rivers flow, water from irrigation canals, brackish and desalinized groundwater). High water mineralization (increasing salt content and total hardness of underground water) has resulted in the termination of operation of water-main tanks in lower reaches of Zeravshan river), bacterial contamination (E-coli and pathogenic microorganisms), herbicides and pesticides-killers, defoliants are the reason of deterioration of ecological conditions and growth of diseases.

\section{Conclusions}

1.Strontium and lithium contents exceed the maximum permissible concentration (MPC) in water of Bukhara Region.

2.In the surface water near Akhangaran, Chirchik and Almalyk the content of cadmium, lead and mercury exceed MPC.

3.In the samples of drinking water of Tashkent City and Tashkent Region high cadmium and mercury concentrations were discovered.

4.Drinking water deficit and its poor quality are typical in the Aral Region. Water deficit is caused by excessive water withdrawal for irrigation and drainage of fields. Livestock wastes, agriculture chemicals, urban and industrial wastes, pollute rivers in this region. The high level of intestinal and gastro-intestinal diseases, hepatitis morbidity was observed in this region. The number of people suffering from pathology of alimentary canal, liver and kidney, cardio-vascular diseases is increasing. Esophagus cancer morbidity is the highest in Republic here. However, heavy metals with concentration exceeding MPC were not found in natural and drinking water. The main reasons of high morbidity rate in Aral Region are following:

1. Low-quality of drinking water (Syrdarya and Amydarya Rivers, water from irrigation canals, brackish and desalinized groundwater);

2. Increasing water mineralization, especially in the lower reaches of the rivers;

3. Bacterial contamination (E-coli and pathogenic microorganisms), pollution by pesticides and herbicides, defoliants. 


\section{Environmental Health Risk}

\section{References}

[1] Mirzaev, S.Sh. Problems of complex use and protection of waters of Uzbekistan and way of improving this problem. Urgent problems of propagation of protection of an environment and strengthening of health of the population : Tashkent, pp. 17-20, 1982.

[2] Namazov, M.B. Problems of pollution of water and of the people's health. Urgent problems of propagation of protection of an environment and strengthening of health of the population : Tashkent, pp.134-135, 1982.

[3] Reference book. Normative methods of analysis of drinking water: Moscow, pp.1-215, 1981.

[4] RD 52.24.24.30-86. Methodical instructions on definition of the contents of mercury in natural waters, VNIIVO Government Committee of Nature of USSR: Moscow , pp. 1-8, 1990.

[5] Kariakin, A.V.\& Gribovsky I.F. Methods of optical spectroscopy and luminescence in analysis of natural and waste water, Chemistry: Moscow, pp.280-303, 1987.

[6] $\mathrm{RD}$ 52.24.28-86. Methodical instructions on Atomic Absorption and electro-thermal definition of heavy metals ( $\mathrm{Cd}, \mathrm{Pb}, \mathrm{Zn}, \mathrm{Ag}, \mathrm{Cu}, \mathrm{Mn}, \mathrm{Cr}, \mathrm{Co}$, $\mathrm{Ni}$ ) and berullium in natural and cleared waste water, VNIIVO Government Committee of Nature of USSR: Moscow , pp. 1-15, 1990.

[7] Methodical instructions on definition of damage from pollution and deterioration of soils in republic of Uzbekistan, Government Committee of Nature of Uzbekistan: Tashkent , pp. 15-16, 1993.

[8] Sanitary rules and norms of protection of surface waters from pollution, confirmed by Ministry of Health No1521-76 from November 181976 : Tashkent , pp.1-105, 1988.

[9] Kamiljanov ,A.Kh. Statuses of air pool in area of an arrangement of Almalyk's Mining Industry Integrated Plant and improving measures. Urgent problems of propagation of protection of an environment and strengthening of health of the population: Tashkent, pp.108-109, 1982.

[10] Perevozchikov, G.V. Why the geologists should be engaged in ecological researches . Ecological bulletin of Uzbekistan, v.1, pp.43-44,1995. 